\title{
Pulsed-wave Doppler Ultrasound in canine reproductive system - Part 2: use in the routine
}

\author{
Ultrassonografia em modo Doppler pulsado no sistema reprodutor canino - Parte 2: uso na Rotina \\ Ecografía Doppler de onda pulsada en el aparato reproductor canino - Parte 2: uso rutinario
}

\author{
Camila Franco de Carvalho \\ ORCID: http://orcid.org/0000-0002-5233-6548 \\ Universidade Federal de Jataí, Brazil \\ E-mail: camilafcarvalho@gmail.com \\ Jéssica Ribeiro Magalhães \\ ORCID: http://orcid.org/0000-0001-8165-9365 \\ Universidade Federal de Jataí, Brazil \\ E-mail: jessicarmedvet@gmail.com \\ Andreia Moreira Martins \\ ORCID: http://orcid.org/0000-0002-8283-9779 \\ Universidade Federal de Jataí, Brazil \\ E-mail: andreia_dover@hotmail.com \\ Kyrla Cartynalle das Dores Silva Guimarães \\ ORCID: http://orcid.org/0000-0002-6194-1280 \\ Universidade Federal de Jataí, Brazil \\ E-mail: kynally83@hotmail.com \\ Reiner Silveira de Moraes \\ ORCID: http://orcid.org/0000-0002-1468-2968 \\ Universidade Federal de Jataí, Brazil \\ E-mail: rmoraes@ualberta.ca \\ Daniel Bartoli de Sousa \\ ORCID: http://orcid.org/0000-0003-3209-7911 \\ Universidade Federal de Jataí, Brazil \\ E-mail: daniel_bartoli_sousa@ufg.br \\ Andréia Vitor Couto do Amaral \\ ORCID: https://orcid.org/0000-0001-6406-2372 \\ Universidade Federal de Jataí, Brazil \\ E-mail: andreiavcvet@ufg.br
}

\begin{abstract}
Given the importance of the reproduction field combined with the use of the Pulsed-Wave (PW) ultrasound in the clinical routine, this study aims to review the application of this diagnostic method in the reproductive tract of females and males of the canine species. A narrative review was carried out by using scientific articles, monographs, dissertations and thesis published and available in online databases: Periodical Capes (Coordination for the Improvement of Higher Education Personnel), SciELO (Scientific Electronic Library Online) and Google Scholar, in addition to specific books on the topic. In female dogs, Doppler ultrasound can be used to evaluate hemodynamic conditions in the estrous cycle (e.g. estimating day of ovulation and fertility, diagnosing early pregnancy, abnormalities, and fetal stress, thus ensuring greater obstetric safety) and identification of diseases, thereby avoiding unnecessary surgical interventions. In male dogs, however, Doppler ultrasound is mainly used in vascular evaluations in order to identify hemodynamic changes due to occurrence of benign prostatic hyperplasia (BPH), most common disease of the prostate and in the assessment of testicular arteries to better understand spermatogenesis and diseases that affect the testicle. In this review, we demonstrate that the use of Doppler mode ultrasound, especially the PW, allows dynamic analysis in clinical examination and complements important information in the diagnosis and treatment of different reproductive disorders in dogs.
\end{abstract}

Keywords: Estrous cycle; Pregnancy; Prostate; Ultrasound.

\section{Resumo}

Diante da importância da área da reprodução aliado ao uso do Pulsed-Wave (PW) ultrassom na rotina, este estudo tem como objetivo fazer uma revisão da aplicação deste método de diagnóstico no trato reprodutor de machos e fêmeas da espécie canina. Realizou-se uma revisão narrativa, utilizando artigos científicos, monografias, teses e dissertações publicadas e disponíveis nas bases de dados online: Periódico Capes (Coordenação de Aperfeiçoamento de Pessoal de Nível Superior), SciELO (Scientific Electronic Library Online) e Google Acadêmico, além de livros específicos do tema Nas cadelas são observadas alterações hemodinâmicas no ciclo 
estral que podem indicar o dia da ovulação e estimar a fertilidade, aumentando a eficiência reprodutiva; que permitem realizar diagnóstico de gestação precoce e reconhecer anormalidades e estresse fetal, assegurando maior segurança obstétrica; e reconhecimento de enfermidades, evitando que sejam realizadas intervenções cirúrgicas desnecessárias. Nos machos as principais utilizações se encontram no conhecimento da vascularização e compreensão das transformações hemodinâmicas ocorridas na hiperplasia prostática benigna (HPB), principal afecção ocorrida na próstata, e na avaliação das artérias testiculares, melhorando o aprendizado sobre a espermatogênese e no diferencial de enfermidades ocorridas no testículo. Nesta revisão, observou-se que a utilização do ultrassom modo Doppler, principalmente o PW, permite a análise dinâmica no exame clínico e complementa informações importantes no diagnóstico e tratamento dos diversos distúrbios reprodutivos em cães.

Palavras-chave: Ciclo estral; Gestação; Próstata; Ultrassom.

\section{Resumen}

Dada la importancia del área de reproducción combinada con el uso de la ecografía de onda pulsada (PW) en la rutina, este estudio tiene como objetivo revisar la aplicación de este método de diagnóstico en el tracto reproductivo de machos y hembras de la especie canina. Se realizó una revisión narrativa, utilizando artículos científicos, monografías, tesis y disertaciones publicados y disponibles en bases de datos en línea: Periodical Capes (Coordinación para el Perfeccionamiento del Personal de Educación Superior), SciELO (Scientific Electronic Library Online) y Google Scholar, además libros específicos sobre el tema. En las perras se observan cambios hemodinámicos en el ciclo estral, que pueden indicar el día de la ovulación y estimar la fertilidad, aumentando la eficiencia reproductiva; que permitan diagnosticar el embarazo precoz y reconocer anomalías y estrés fetal, garantizando una mayor seguridad obstétrica; y reconocimiento de enfermedades, evitando intervenciones quirúrgicas innecesarias. En el sexo masculino, los principales usos están en el conocimiento de la vascularización y comprensión de las transformaciones hemodinámicas que ocurrieron en la hiperplasia prostática benigna (HPB), la principal condición que ocurre en la próstata, y en la evaluación de las arterias testiculares, mejorando el aprendizaje sobre la espermatogénesis y el diferencial de enfermedades que han ocurrido en el testículo. En esta revisión, se observó que el uso de la ecografía en modo Doppler, especialmente el PW, permite el análisis dinámico en el examen clínico y complementa información importante en el diagnóstico y tratamiento de diversos trastornos reproductivos en perros.

Palabras clave: Ciclo estral; El embarazo; Próstata; Ultrasonido.

\section{Introduction}

The knowledge on canine reproductive physiology has considerably increased over the years, as well as diagnostic methods to assist veterinarians (Jitpean et al., 2017; Hagman, 2018). Among the diagnostic methods, the Pulsed-Wave (PW) ultrasound has become part of the routine evaluation of the reproductive system in several species, as the study of hemodynamics and flow characteristics provides important information for understanding morphological and physiological aspects of it. Pathogenic processes can be differentiated through hemodynamic changes, augmenting the diagnosis and prognosis (Holen, 2014; Bonacerraf et al., 2015; Nogueira et al., 2017; de Freitas et al., 2017).

The blood flow parameters analysis includes mainly the peak systolic velocity (PSV) and the end diastolic velocity (EDV), which give rise to the dopplervelocimetric index of resistivity (RI) and pulsatility (PI), allowing the understanding of the vascular bed compliance. Variations in these indices help to identify transformations in the compliance of the vascular bed under study, associated with parenchymal dysfunctions or characterization of disease malignancies, complementing information on the prognosis (Carvalho et al., 2008; Nogueira et al., 2017).

The use of Pulsed-Wave ultrasound is still the subject of recent studies in veterinary medicine. In female dogs, it has been mainly used to evaluate physiological aspects of the estrous cycle, gestational aspects, and differentiation of uterine diseases, whereas in male dogs, it has been used for prostatic and testicular disorders diagnosis (Carvalho et al., 2008; Nogueira et al., 2017). Given the importance of the reproduction field combined with the use of the Pulsed-Wave ultrasound in the routine, this study aims to review the application of this diagnostic method in the reproductive tract of females and males of the canine species. 


\section{Methodology}

A narrative review was carried out using scientific articles, monographs, dissertations and thesis published and available in online databases: Periodical Capes (Coordination for the Improvement of Higher Education Personnel), SciELO (Scientific Electronic Library Online) and Google Scholar, in addition to theme-specific books. According to the methodology cited by Pinto et al. (2021), studies that did not address the main theme under analysis were excluded, as well as articles with opinions that were not supported by research data.

The use of PW ultrasound in the routine to assess canine reproductive tract was organized in procedures in canine females and canine males. The technical aspects of Pulsed-Wave ultrasound (physical principles, processing and interpretation of Doppler spectral images, technical adjustments and main artifacts observed) are available in part 1. To illustrate, photographs of ultrasound examinations performed on dogs in the medical clinic of the Veterinary Hospital of the Federal University of Jataí (HV/UFJ) were used. All procedures were performed by prior signing the consent form of the owner or responsible for the animal, following the protocols of the HV/UFJ and Ethics in Animal Experimentation (CEUA 008/2018).

\section{Use of Doppler ultrasound in the canine reproductive routine}

\subsection{Female dogs}

\subsubsection{Evaluation of estrous cycle}

The estrous cycle in female dog presents different characteristics compared to female individuals of other species, being dogs considered monoestrous plus other phases of cycle as the proestrus, estrus, diestrus and anestrus. Important changes in ovarian and uterine vascularization occur in each of these phases, due to actions promoted by the estrogen and progesterone hormones (Concannon, 2011).

The estrous cycle starts in the proestrus, and it is characterized by the development of the ovarian follicles and increasing in estrogen production, evidenced by vulvar serosanguineous discharge. The second phase is the estrus, in which follicles increase in size, and ovulation occurs approximately from one to three days after an increase in the luteinizing hormone ( $\mathrm{LH})$. During this process, there is a reduced production of estrogen hormone, elevation in progesterone, and reduction in vulvar discharge. Subsequently, there is an increase in fertility (Vermeulen, 2009; Concanoon, 2011).

Although there are certain aspects that may be visually perceived (e.g. distinguishing between proestrus and estrus phases by the reduction of vulvar discharge and acceptance of the male by the female), these aspects are not totally reliable in determining the exact moment of ovulation. This information can be obtained by using other methods such as vaginoscopy, vaginal cytology and hormonal assessment. However, these methods also have limitations, as they are invasive tests, expensive or not accurate (Vermeulen, 2009; Concanoon, 2011; Bergeron et al., 2013).

The ovarian B-mode ultrasound can detect the exact moment of ovulation, however, there are few circumstances that can make it difficult to distinguish between pre-ovulatory follicles and precisely formed corpus luteum (CL), even when a change in the thickness of the wall of CL can be seen (Vermeulen, 2009; Matoon \& Nyland, 2015). In addition, the luteinization of the follicles can occur during ovulation and the follicles can collapse, but the release of oocyte is not always observed (Bicudo et al., 2010; Bergeron et al., 2013). Moreover, the follicles development is not simultaneous in occurrence and the follicles that do not ovulate can remain inside the ovary (Bicudo et al., 2010; England et al., 2012). Such events are dependent on the experience of the imaging professional, and consequently, due to the absence of experience, the examination is not routinely performed in clinical practice.

The Doppler ultrasound can identify changes that may occur in the ovarian vascularization and in the Doppler velocimetric indices based on events such as ovulation and formation of corpus luteum (CL) (Pellerito, 2012), which are 
presented as changes in the ovarian arteries and in the uterus as a result of endometrial neoangiogenesis (Barbosa et al., 2013). Approximately one day before ovulation, there is a significant increase in ovarian blood flow, allowing for observation of larger areas and intense colors when using the Color Doppler (CD) ultrasound (Pellerito, 2012; Barbosa et al., 2013) and an increase in PSV and EDV with PW ultrasound (Bicudo et al., 2010; Barbosa et al., 2013; Jurczak \& Janowski, 2018). The released LH induces arterial dilation, making the vascular bed more compliant and reducing the RI (Bergeron et al., 2013). Therefore, two recent studies reported an increase in PSV and EDV with no changes in RI during the periovulatory period (Freitas et al., 2017; Jurczak \& Janowski, 2018). Thus, performing daily imaging examination from the beginning of the proestrus phase seems to be more reliable in verifying these indices and so, identifying the exact moment when changes in the Doppler velocimetric indices occur.

The uterine artery also shows changes in the vascular pattern according to the phase of the estrous cycle. During the proestrus and estrus phases in female dogs, a continuous flow of high resistivity and speed is observed, and this condition shows a distinct PSV followed by a small diastolic peak, in addition to changes in Doppler velocimetric indices similar to those observed in the ovarian artery (Barbosa et al., 2013; Freitas et al., 2017; Jurczak \& Janowski, 2018). However, the RI can be related to the age of the dog and history of previous pregnancies. For females, high values of RI observed in the uterine artery during ovulation may indicate decreased uterine perfusion and fertility (Freeman et al., 2013; Freitas et al., 2017; Jurczak \& Janowski, 2018).

Diestrus is the phase following estrus. It lasts about 60 days, and is characterized by the formation of CL and the returning of sexual hormones to baseline values. Anestrus is the last phase of the estrous cycle, a phase that lasts about 120 days. It is characterized by the complete vulvar regression to its normal size, regression of the formed CL, endometrial repair and return to baseline concentration of all hormones until the beginning of a new cycle (Vermeulen, 2009; Concanoon, 2011; Bergeron et al., 2013). Regarding the hemodynamic indices in these phases, there is a reduction in PSV, EDV and an increase in RI until the beginning of another cycle (Lacerda, 2015; Nogueira et al., 2017).

\subsubsection{Pregnancy}

A healthy pregnancy is a desired outcome for the breeder and owner of the breeding kennel, and it is up to the veterinarian imaging professional to conduct a reliable examination to detect early maternal and fetal changes. In this sense, the early gestational diagnosis allows the differentiation of diseases at an early stage and so, rapid establishment of a therapeutic protocol, preserving the reproductive tract function (Feliciano et al., 2013).

The evaluation of the ovarian artery blood flow around two weeks after natural mating or artificial insemination through PW ultrasound allows the assessment of whether the hemodynamic changes are due to a gestational process. A study carried out in 2013 compared hemodynamic indices in female dogs in the diestrus phase and pregnant female dogs throughout the gestational period. In this study, the authors observed that there was a reduction in PSV and EDV in both conditions with lower lower values for these variables, plus reduced RI in pregnant dogs (Polisca et al., 2013). Similar results were also found by Feliciano et al. (2013), who reported a reduction in these indices approximately 12 to 14 days from conception, and this the pregnancy confirmation in its initial stage even before the visualization of the gestational vesicula.

The uterine artery can also be used for the same purpose. Lower values of RI and PI are observed in pregnant dogs when compared to non-pregnant dogs approximately 30 days after ovulation (Roos et al., 2020), and there is a progressive increase in uterine blood flow, Plus, there is a gradual reduction in RI from 0.64 to 0.52 at 30 days of gestation and predelivery, respectively (Batista et al., 2018; Roos et al., 2020). However, the dog's age is a factor that can cause changes in the successful detection of pregnancy, as older dogs present a relative absence of spectral diastole in the uterine artery, lower EDV, and higher RI (Freeman et al., 2013; Freitas et al., 2017). Other factors that can conduct to elevated RI during pregnancy 
are: early embryonic death with absorption (Freitas et al., 2016), fetal abnormalities (Feliciano et al., 2014; Freitas et al., 2016) and reduced blood flow due to abnormal development of placental vascular, which can cause intrauterine growth restriction and miscarriage (Blanco et al., 2008; Blanco et al., 2009; Blanco et al., 2011).

The study of fetal vessels has also been relevant, mainly in order to predict the time of delivery and avoid unnecessary fetal stress. As the pregnancy approaches the end, there is a decrease of RI in the umbilical artery (Miranda \& Domingues, 2010; Giannico et al., 2015). Measurements below 0.7 in the fetus indicate that the delivery is imminent and the values detection in all fetuses can correspond to birth in about 12 hours (Giannico et al., 2016; Umamageswari et al., 2018).

The early observation of fetal stress (before the appearance of heart rate below 200 beats per minute) can be noted by constant RI values in the umbilical artery (between 0.7 to 0.8) in the last days of pregnancy (Oliveira, 2013; Giannico et al., 2016; Umamageswari et al., 2018). This situation indicates that the pregnant dog should be monitored more closely, and the Csection performed to avoid fetuses death. This is important in some breeds that have difficulties in carrying out eutocic delivery (e.g. Bulldog) because despite the necessary hospitalization for ultrasound examination, it is safer than just monitoring the fetal heart rate. After delivery, hemodynamic changes occur during the uterine regression period, observing higher RI and lower EDV values in comparison to natural delivery when C-section is performed in the dog (Barbosa et al., 2018).

\subsubsection{Uterine diseases}

Uterine diseases that cause accumulation of luminal secretion are the most prevalent in the reproductive field and cause uterine vascular changes. Although changes are subtle, such as mucometra and endometrial hyperplasia, diseases cause changes in the ultrasound spectrum. They present both an intermediate resistivity pattern when compared to animals without changes and a reduction in RI to values between 0.7 and 0.8 (Figure 1A), which helps in the patients' diagnosis (Batista et al., 2016; Veiga et al., 2017).

Figure 1. Pulsed-wave Doppler and B-mode ultrasound image of the uterine artery of a female dog without uterine changes, showing IR values between 0.8 and 0.9 (A) and of a female dog showing pyometra, with an IR value below 0.7 (B).

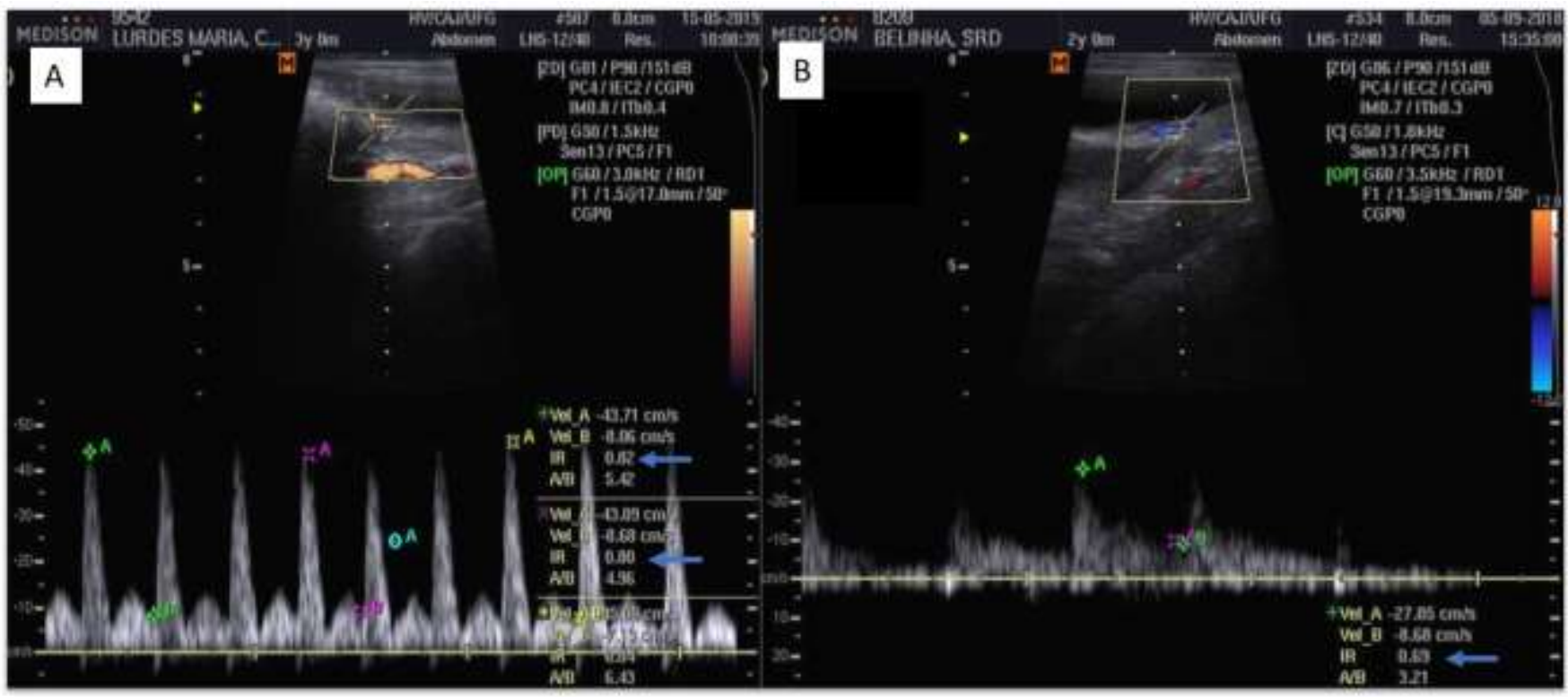

Source: Authors.

In cases where signs of infections appear (Figure 2), the demand of metabolites and oxygen increases, and the presence of vasodilation cytokines causes a decrease in the distal vascular tone (Carvalho et al., 2008; Veiga, 2012; Holen, 
2014). The metabolic changes are reflected in both the ultrasound spectrum, and change in the hemodynamic pattern to high speed and low resistance with RI ranging from 0.6 to 0.7 - Figure 1B (Batista et al., 2015; Lacerda, 2015; Veiga et al., 2017).

Figure 2. Pulsed wave Doppler, color Doppler and B-mode ultrasound image of the uterine artery in a female dog pyometra closed, showing flow at high speed, but with low resistivity.

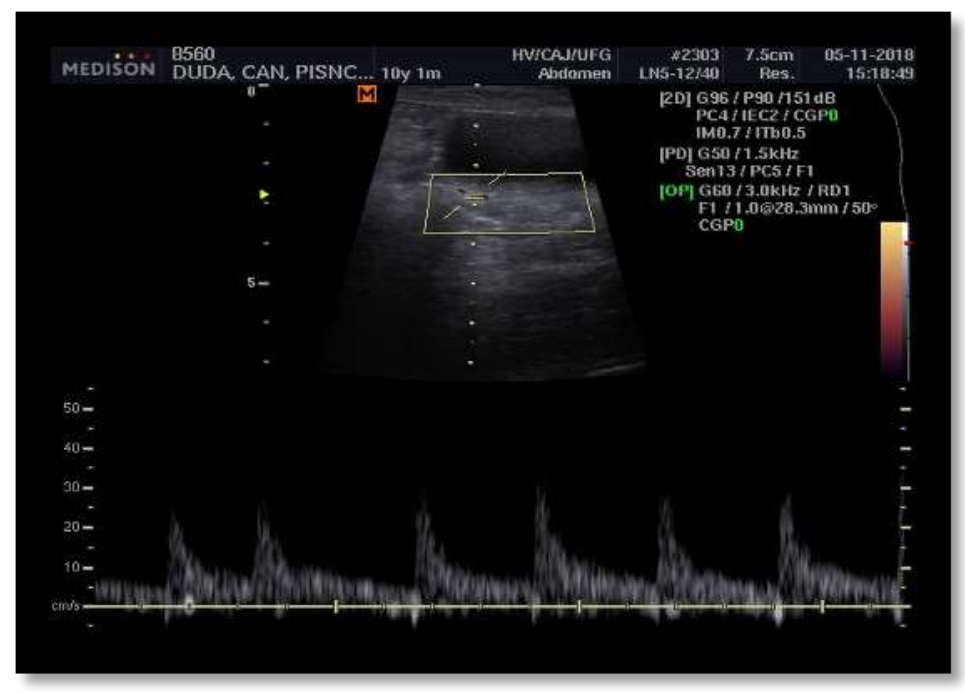

Source: Authors.

In females, the presence of uterine fibroids or polyps also causes spectral changes and allows the differential diagnosis of uterine neoplasms (Roos et al., 2020). However, no studies on female dogs reporting vascular changes observed in endometrial neoformations were found.

\subsection{Male dogs}

\subsubsection{Prostate}

The prostatic artery has a small diameter and branches into cranial, subcapsular, parenchymal, and caudal portions. In a study evaluating healthy adult dogs (Boxer, 5-7 years-old) using CD and PW ultrasound, Freitas et al. (2013) detected intense flow in the cranial and caudal regions, moderate flow in the subcapsular region, and discreet flow in the parenchymal portion.

In the spectrum, biphasic waves were found in the cranial and caudal portions with a thin systolic peak followed by a small parabolic diastolic peak. This indicates a high resistance flow and, in the subcapsular and parenchymal parts, a monophasic spectrum was observed with a small and wide systolic peak followed by a diastolic peak with decreasing speed, corresponding to low resistance flow. Regarding the hemodynamic indices, PSV and EDV values were similar in the different portions of the prostatic artery, however, the RI and PI were lower in the subcapsular and parenchymal fractions (Freitas et al., 2013).

Similar results were found in another study evaluating French Bulldog male adults, but older dogs showed an increase in prostate volume and higher RI and PI when compared to young dogs with normal prostate volume (Freitas et al., 2015). When performing the prostate examination using Doppler ultrasound, it must be noted whether the animal has had recent sexual contact once there is an immediate increase in vascular flow up to 18 hours after ejaculation. This episode does not necessarily relate to clinical signs of illness. The PSV and EDV values increase, and there is a reduction in RH in the 
cranial, caudal, parenchyma portions, as well as an increase in the capsular region. Therefore, sexual inactivity is recommended up to 24 hours before examination with Doppler techniques, so that physiological conditions are not misinterpreted as pathological ones (Alonge et al., 2017; Alonge et al., 2018).

The prostate can undergo physiological changes in size according the dog age, breed, body weight, and sexual maturity (Freitas et al., 2015). The benign prostatic hyperplasia (BPH) is commonly found in intact dogs and dogs over 5years-old (Polisca et al., 2013; Zelli et al., 2013; Leoci et al., 2014), which causes hyperplasia, cellular hypertrophy, and an increase in blood perfusion in the organ (Angrimani et al., 2018).

When comparing the differences in hemodynamic indices of the prostatic artery of healthy, intact dogs, and dogs with BPH, Zelli et al. (2013) reported higher PSV and EDV velocities in the BPH group compared to normal dogs. Regardless of the group, Doppler ultrasound showed continuous blood flow with a biphasic pattern characterized by a systolic peak with low EDV. However, values of RI and PI were not different between groups, indicating that RI is not a predictive parameter for recognizing $\mathrm{BPH}$ in dogs.

In a recent study assessing the hemodynamics and vascular characteristics of dogs prostate with BHP and treated with Finasteride, Angrimani et al. (2018) found higher prostate volume in all dogs evaluated before starting the treatment. The increase in local angiogenesis followed by an increase in blood flow from the prostatic artery accompanied the increase in prostate volume, also presenting lower PSV and greater EDV in the prostatic artery of dogs with BPH. After 60 days of treatment, the authors found a reduction in prostate volume and local vascularization.

Polisca et al. (2013) also evaluated the hemodynamics of the prostatic artery in dogs with asymptomatic BPH, and they found a reduction in blood flow and PSV and EDV over further treatment with GnRH analogue. Although methods such as rectal palpation, B-mode ultrasound, and semen analysis are common practices, the use of the correlation of prostate volume with Doppler velocimetric indices revealed that this imaging evaluation is also an important tool to monitor the treatment of prostate disorders.

\subsubsection{Testicles}

Doppler ultrasound has helped the understanding of the anatomy and functionality of blood vessels (Souza et al., 2014). This has allowed the diagnosis of testicular pathologies that affect scrotal blood flow, evaluation of spermatogenesis, and understanding of the testicular artery behavior, factors that are analyzed by vascular structure, presence or absence of blood flow, direction and velocity (Carrillo et al., 2012; Souza et al., 2014; Souza \& Silva, 2014).

Carrillo et al. (2012) analyzed the blood flow of testicles of healthy dogs for 6 months, dividing the testicular artery into: supratesticular artery in the spermatic cord (cranial part and in "loop"), marginal or capsular artery, and intratesticular vessels. The authors noted that the supratesticular arteries were tortuous and presented a directional flow, in which the cranial portion showed a distinct flow of highly resistant vessels with high values of RI and PI. The marginal arteries were visualized on the outside surface of the testis, showing unidirectional flow.

In contrast, the intratesticular vessels appeared straight in the testicular parenchyma, but with bidirectional flow. The blood flow was characterized with low resistance pattern in the looped part of the supratesticular artery, the marginal artery, and the intratesticular vessels, presenting low RI and PI (Carrillo et al., 2012).

An increase in PSV was found in the cranial part of the supratesticular artery, but the PSV decreased in the marginal artery and intratesticular vessels. In addition, EDV showed lower values in the intratesticular vessels and higher values in the looped portion of the supratesticular and marginal arteries. Moreover, the RI was found to be a reliable parameter to assess blood flow and differentiate cases of obstructive azoospermia from non-obstructive cases (Carrillo et al., 2012). 
In another study using Doppler ultrasound to evaluate the anatomy of the vessels and the blood flow of the testicles, Souza et al. (2014) reported that the spermatic cord showed a tortuous pattern. In addition, the blood flow showed a low resistance monophasic pattern in both spermatic cord and marginal portion of the testicular artery, presenting a more evident systolic peak in the spermatic cord. EDV was higher in the marginal artery compared to the spermatic cord, but it presented lower RI and PI.

Souza et al. (2014) compared the testicular flow of animals of different physical sizes and observed higher PSV and EDV in larger animals, whereas RI and PI were higher in small dogs, possibly due to the length of the testicular artery that varies with weight. When comparing the data only considering the location, higher values of PSV, EDV, RI, and PI were observed in the spermatic cord region, and reduced values in the marginal artery and intratesticular vessels, sequentially.

In a study evaluating the blood supply to the testicles, Trautwein et al. (2019) subdivided the testicular artery into supratesticular (proximal, medial, distal), marginal, and intratesticular. In the supratesticular region (proximal and medial), the ultrasound waves showed medium to high resistivity with a distinct systolic peak. There were low and wide systolic peaks with low resistivity in the distal region of the supratesticular, marginal, and intratesticular artery. Blood flow velocity, resistivity, and pulsatility of the testicular artery decreased as it entered the testicle. This can be explained by the prolongation of the artery and its tortuosity, which branched from the vessels when entering the testicular parenchyma. Such characteristics influence RI and PI by contributing to a constant flow to the organ.

\subsubsection{Testicular neoplasms}

Bigliardi et al. (2019) evaluated healthy dogs with clinical signs of testicular diseases and showed areas with hypoand hyper-vascularity in the testicles (detected using CD ultrasound), thus verifying whether there were differences in testicular hemodynamic indices based on PW Doppler velocimetric indices. After detection, the animals were referred for orchiectomy surgery and histopathological analysis of the affected testicle. The authors found that the testicular neoplasms represented $80 \%$ of the evaluated lesions, and the $\mathrm{CD}$ ultrasound showed an increase in intralesional and peripheral flow to the tumor. Regarding the velocimetric indices, PSV increased with the increase in size of nodules and presented a low resistance flow in neoplastic cases.

Inflammatory and degenerative lesions were also found by Bigliardi et al. (2019) presenting increased RI when inflammation was present and decreased RI when degenerative qualities were observed. The knowledge of blood perfusion in testicular changes can help to better understand the origin of the pathological processes, especially in cases where the dog's owner does not want to perform the orchiectomy or cannot be performed quickly enough due to other reasons.

\subsubsection{Spermatogenesis}

A Doppler ultrasound study comparing dogs with and without sperm changes found that the first group had lower systolic pressure waves peak, PSV and EDV throughout the entire testicular artery, and did not present changes in RI. This is attributed to the existence of more linear vessels with smaller diameter, which resulted in reduced flow without reducing RI (Souza et al., 2015).

Zelli et al. (2013) assessed the relationship between spermatogenesis and blood flow in testicles. They also found that Doppler waves in the testicular artery have low resistance and slow systolic flow, followed by a long and single-phase diastolic flow. In addition, the authors found that PSV was positively correlated with testicular volume. Both RI and PI showed a negative correlation with sperm motility and the percentage of spermatozoa with an intact membrane and curled tails. The latter, however, correlated positively with the EDV. The authors reported that both RI and PI can be used to assist in the 
reproductive evaluation and seminal quality in dogs, since their evaluations do not rely on the angle of insonation chosen by the operator.

\section{Final Considerations}

In this review, we demonstrate that the use of Doppler mode ultrasound, especially the PW, allows a dynamic analysis in clinical examination and complements important information in the diagnosis of different reproductive disorders in dogs.

\section{References}

Alonge, S., Melandri, M., Leoci, R., Lacalandra, G. M. \& Aiudi, G. (2018). Ejaculation effect on blood testosterone and prostatic pulsed- wave Doppler ultrasound in dogs. Reprod Dom Anim, 53(Suppl. 2), 70-73. https://doi. org/10.1111/rda.13277.

Alonge, S., Melandri, M., Fanciullo, L., Lacalandra, G. M. \& Aiudi, G. (2017). Prostate vascular flow: The effect of the ejaculation on the power doppler ultrasonographic examination. Reprod Dom Anim, 53(1), 1-6. https://doi. org/10.1111/rda.13078.

Angrimani, D. S. R., Silvestrini, G. R., Brito, M. M., Abreu, R. A., Almeida, L. L. \& Vannucchi, C. I. (2018). Effects of benign prostatic hyperplasia and finasteride therapy on prostatic blood flow in dogs. Theriogenology, 114, 103-108. Doi: 10.1016/j.theriogenology.2018.03.031.

Barbosa, C. C., Souza, M. B., Freitas, L. A., Silva, T. F. P., Domingues, S. F. S. \& Silva, L. D. M. Assessment of uterine involution in bitches using B-mode and Doppler ultrasonography. Anim Reprod Sci, 139:121-126. Doi: 10.1016/j.anireprosci.2013.02.027.

Barbosa, C. C., Souza, M. B., Scalercio, S. R. R. A., Silva, T. F. P., Domingues, S. F. S. \& Silva, L. D. M. Ovarian and uterine periovulatory Doppler ultrasonography in bitches. Pesq. Vet. Bras, 33(9), 1144-1150. http://dx.doi.org/10.1590/S0100-736X2013000900016.

Batista, P. R., Gobello, A. R., Corrada, Y. A., Tórtora, A. M. \& Blanco, P. G. (2016). Uterine blood flow evaluation in bitches suffering from cystic endometrial hyperplasia (CEH) and CEH-pyometra complex. Theriogenology, 85, 1258-1261. Doi:10.1016/j.theriogenology.2015.12.008.

Batista, P. R., Gobello, C., Rube, A., Barrena, J. P., Re, N. E. \& Blanco, P. G. (2018). Reference range of gestational uterine artery resistance index in small canine breeds. Theriogenology, 114, 81-84. Doi:10.1016/j.theriogenology.2018.03.015.

Benacerraf, B. R., Abuhamad, A. Z., Bromley, B., Goldstein, S. R., Groszmann, Y., Shipp, T. D. \& Timor-Tritsch, I. E. (2015). Consider ultrasound first for imaging the female pelvis. Am J Obstet Gynecol, 212(4), 450-455. Doi: 10.1016/j.ajog.2015.02.015.

Bergeron, L. H., Nykampb, S. G., Brissonb, B. A., Madana, P., Gartleyc, C. J. (2013). An evaluation of B-mode andcolor Doppler ultrasonographyfordetecting periovulatory events in the bitch. Theriogenology, 79(2), 274-283. Doi: 10.1016/j.theriogenology.2012.08.016.

Bicudo, A. L. C., Mamprim, M. J., Lopes, M. D., Vulcano, L. C. \& Derussi, A. A. P. (2010). Avaliação ultra-sonográfica convencional e dopplerfluxométrica durante a fase folicular do ciclo estral de cadelas. Vet. e Zootec, 17(4), 507-518.

Bigliardi, E., Denti, L., De Cesaris, V., Bertocchi, M., Di Ianni, F., Parmigiane, E., Bresciani, C. \& Cantoni, A. M. (2019). Colour doppler ultrasound imaging of blood flows variations in neoplastic and non-neoplastic testicular lesions in dogs. Reproduction in Domestic Animals, 54(1), 63-71. Doi: 10.1111/rda.13310.

Blanco, P. G., Arias, D. O. \& Gobello, C. (2008). Doppler Ultrasound in Canine Pregnancy. J Ultrasound Med, 27, 1745-1750. Doi: 10.7863/jum.2008.27.12.1745.

Blanco, P. G., Arias, D. O., Rube, A., Barrena, J. P., Corrada, Y. \& Gobello, C. (2009). Experimental Model to Study Resistance Index and SystolicDiastolic Ratio of Uterine Arteries in Adverse Canine Pregnancy Outcome. Reprod Dom Anim, 44, 164-166. Doi: 10.1111/j.1439-0531.2009.01369.x.

Blanco, P. G., Rodríguez, R., Rube, A., Arias, D. O., Tórtora, M., Díaz, J. D. \& Gobello, C. (2011). Doppler ultrasonographic assessment of maternal and fetal blood flow in abnormal canine pregnancy. Animal Reproduction Science, 126, 130-135. Doi: 10.1016/j.anireprosci.2011.04.016.

Carrillo, J. D., Soler, M., Lucas, X. \& Agut, A. (2012). Colour and pulsed doppler ultrasonographic study of the canine testis. Reproduction in Domestic Animals, 47, 655-659. Doi: 10.1111/j.1439-0531.2011.01937.x.

Carvalho, C. F., Chammas, M. C. \& Cerri, G. G. (2008). Princípios físicos do Doppler em ultra-sonografia. Ciência Rural, 38, 872-879. Doi:10.1590/s010384782008000300047 .

Concannon, P. W. (2011). Reproductive cycles of the domestic bitch. Animal Reproduction Science, 124(3), 200-210. https://doi.org/10.1016/j.anireprosci.2010.08.028.

De Freitas, L. A., Mota, G. L., Silva, H. V. R. \& da Silva, L. D. M. (2017). Two-dimensional sonographic and Doppler changes in the uteri of bitches according to breed, estrus cycle phase, parity, and fertility. Theriogenology, 95, 171-177. Doi: 10.1016/j.theriogenology.2017.03.012.

England, G. C. W., Moxon, R. \& Freeman, S. L. (2012). Delayed uterine fluid clearance and reduced uterine perfusion in bitches with endometrial hyperplasia and clinical management with postmating antibiotic. Theriogenology, 78, 1611-1617. Doi:10.1016/j.theriogenology.2012.07.009.

Feliciano, M. A. R., Nepomuceno, A. C., Cardilli, D. J., Nassar, C. L., Oliveira, M. E. F., Kirnew, M. D., Almeida, V. T. \& Vicente, W. R. R. (2013). B-mode Ultrasound and Doppler Mode for Early-stage Pregnancy Diagnosis in Shi-Tzu Bitches. Acta Scientiae Veterinariae, 41(1), 1-6. 
Feliciano, M. A. R., Nepomuceno, A. C., Cardilli, D. J., Nassar, C. L., Oliveira, M. E. F., Kirnew, M. D., Almeida, V. T. \& Vicente, W. R. R. (2014). Triplex Doppler Ultrassonography in Prenatal of Pregnant Bitches. Acta Scientiae Veterinariae, 42(1), 1-5.

Freeman, S. L., Russo, M. \& England, G. C. W. (2013). Uterine artery blood flow characteristics assessed during oestrus and the early luteal phase of pregnant and non-pregnant bitches. Vet J, 197, 205-210. Doi:10.1016/j.tvj1.2013.02.015.

Freitas, L. A., Pinto, J. N., Silva, H. C. R. \& da Silva, L. D. M. (2015). Two-dimensional and Doppler sonographic prostatic appearance of sexually intact French Bulldogs. Theriogenology, 83(7), 1140-1146. https://doi.org/10.1016/j.theriogenology.2014.12.016.

Freitas, L. A., Pinto, J. N., Silva, H. C. R., Daniel, C. U., Mota Filho, A. C. \& Silva, L. D. M. (2013). Doppler e ecobiometria prostática e testicular em cães da raça Boxer. Acta Scientiae Veterinariae, 41(1), 1-8.

Freitas, L. A., Mota, G. L., Silva, H. V. R. \& Silva, L. D. M. (2017). Two-dimensional sonographic and Doppler changes in the uteri of bitches according to breed, estrus cycle phase, parity, and fertility. Theriogenology, 95, 171-177. Doi:10.1016/j.theriogenology.2017.03.012.

Freitas, L. A., Mota, G. L., Silva, H. V. R., Carvalho, C. F. \& Silva, L. D. M. (2016). Can maternal-fetal hemodynamics influence prenatal development in dogs?. Anim. Reprod. Sci., 172, 83-93. http://dx.doi.org/10.1016/j.anireprosci.2016.07.005.

Giannico, A. T., Gil, E. M. U., Garcia, D. A. A., Froes, T. R. (2015). The use of Doppler evaluation of the canine umbilical artery in prediction of delivery time and fetal distress. Anim.Reprod.Sci., 154, 105-112. http://dx.doi.org/10.1016/j.anireprosci.2014.12.018.

Giannico, A. T., Garcia, D. A. A., Gil, E. M. U., Sousa, M. G. \& Froes, T. R. (2016). Assessment of umbilical artery flow and fetal heart rate to predict delivery time in bitches. Theriogenology, 86(7), 1654-1661. Doi: 10.1016/j.theriogenology.2016.03.042.

Hagman, R. (2018). Pyometra in Small Animals. Vet Clin North Am Small Anim Pract, 48(4), 639-661. Doi: 10.1016/j.cvsm.2018.03.001.

Holen, J. (2014). Introduction to Vascular Ultrasonography. Radiology, 154. Doi:10.1148/radiology.154.2.442.

Jitpean, S., Ambrosen, A., Emanuelson, U. \& Hagman, R. (2017). Closed cervix is associated with more severe illness in dogs with pyometra. BMC Veterinary Research, 13(1), 1-7. Doi: 10.1186/s12917-016-0924-0.

Jurczak, A. \& Janowski, T. (2018). Arterial Ovarian Blood Flow in the Periovulatory Period of GnRH-induced and Spontaneous Estrous Cycles of Bitches. Theriogenology, 119, 131-136. https://doi.org/10.1016/j.theriogenology.2018.06.014.

Lacerda, M. A. S. (2015). Ultrassonografia Doppler para parâmetros fluxométricos da artéria uterina média de cadelas em estagios fisiológicos e patológico (piometra). [Dissertação de mestrado, Universidade Federal Rural de Pernambuco]. TEDE.

Leoci, R., Aiudi, G., Silvestre, F., Lissner, E. \& Lacalandra, G. M. Effect of pulsed electromagnetic field therapy on prostate volume and vascularity in the treatment of benign prostatic hyperplasia: a pilot study in a canine model. The prostate, 74(11), 1132-1141. Doi: 10.1002/pros.22829.

Matoon, J. S. \& Nyland, T. G. (2015). Ovaries and uterus. In J. S. Matoon. \& T. G. Nyland (Eds.), Small animal diagnostic ultrasound (3 ${ }^{\text {rd }}$ ed., pp. 634-654). WB Saunders.

Miranda, S. A. \& Domingues, S. F. (2010). Conceptus ecobiometry and triplex Doppler ultrasonography of uterine and umbilical arteries for assessment of fetal viability in dogs. Theriogenology, 74(4), 608-617. Doi: 10.1016/j.theriogenology.2010.03.008.

Nogueira, I. B., Almeida, L. L., Angrimani, D. S. R., Brito, M. M., Abreu, R. A. \& Vannucchi, C. I. (2017). Uterine haemodynamic, vascularization and blood pressure changes along the oestrous cycle in bitches. Reprod Domest Anim, 52, 52-7. Doi:10.1111/rda.12859.

Oliveira, D. M. N. M. (2013). Ultrassonografia Doppler triplex de fetos caninos relacionada com a frequência cardíaca fetal. [Dissertação de mestrado, Universidade Federal Rural de Pernambuco]. TEDE.

Pellerito, J. S. (2012). Duplex ultrasound evaluation of the uterus and ovaries. In P. Pellerito (Ed.), Introduction to vascular ultrassonography (6 ${ }^{\text {th }}$ ed., pp. 540558). Elsevier.

Pinto, R. B. B., Ribeiro, K. C., da Silva, M. F., Regalin, D., Meirelles-Bartoli, R. B. \& Amaral, A. V. C. do. (2021). Main anesthetic blocks for eye surgery in dogs and cats. Research, Society and Development, 10(3), 1-8. https://doi.org/10.33448/rsd-v10i3.13719.

Polisca, A., Orlandi, R., Troisi, A., Brecchia, G., Zerani, M., Boiti, C. \& Zelli, R. (2013). Clinical Efficacy of the GnRH Agonist (Deslorelin) in Dogs Affected by Benign Prostatic Hyperplasia and Evaluation of Prostatic Blood Flow by Doppler Ultrasound. Reprod Dom Anim, 48, 673-680. Doi: 10.1111/rda.12143.

Polisca, A., Zellia, R., Troisi, A., Orlandi, R., Brecchia, G. \& Boiti, C. (2013). Power and pulsed Doppler evaluation of ovarian hemodynamic changes during diestrus in pregnant and nonpregnant bitches. Theriogenology, 79(2), 219-224. Doi: 10.1016/j.theriogenology.2012.08.005.

Roos, J., Aubanel, C., Niewiadomska, Z., Lannelongue, L., Maenhoudt, C. \& Fontbonne, A. (2020). Triplex doppler ultrasonography to describe the uterine arteries during diestrus and progesterone profile in pregnant and non-pregnant bitches of different sizes. Theriogenology, 141: 153-160. Doi: 10.1016/j.theriogenology.2019.08.035.

Souza, M. B., Barbosa, A. C. C., Pereira, B. S., Monteiro, C. L. B., Pinto, J. N., Linhares, J. C. S. \& Silva, L. D. M. (2014). Doppler velocimetric parameters of the testicular artery in healthy dogs. Research in Veterinary Science, 96(3): 533-536. Doi: 10.1016/j.rvsc.2014.03.008.

Souza, M. B., England, G. C. W., Mota Filho, A. C., Ackermann, C. L., Sousa, C. V. S., Carvalho, G. G., Silva, H. V. R., Pinto, J. N., Linhares, J. C. S., Oba, E. \& da Silva, L. D. M. (2015). Semen quality, testicular B-mode and Doppler ultrasound, and serum testosterone concentrations in dogs with established infertility. Theriogenology, 84(5), 805-810. Doi: 10.1016/j.theriogenology.2015.05.015.

Souza, M. B., Mota Filho, A. C., Sousa, C. V. S., Monteiro, C. L. B., Carvalho, G. G., Pinto, J. N., Linhares, J. C. S. \& Silva, L. D. M. (2014). Triplex doppler 
Research, Society and Development, v. 10, n. 5, e52610515352, 2021

(CC BY 4.0) | ISSN 2525-3409 | DOI: http://dx.doi.org/10.33448/rsd-v10i5.15352

evaluation of the testes in dogs of diferente sizes. Pesquisa Veterinária Brasileira, 34(11), 1135-1140. https://doi.org/10.1590/S0100-736X2014001100017.

Souza, M. B. \& Silva, L. D. M. (2014). Ultrassonografia bidimensional, Doppler e contrastada para a avaliação testicular: do homem ao animal. Revista Brasileira de Reprodução Animal, 38(2), 86-91.

Trautwein, L. G. C., Souza, A. K. \& Martins, M. I. M. (2019). Can testicular artery Doppler velocimetry values change according to the measured region in dogs? Reproduction in Domestic Animals, 54(4), 687-695. Doi: 10.1111/rda.13410.

Umamageswari, J., Sridevi, P. \& Joseph, C. (2018). Doppler indices of umbilical artery, utero-placental artery and fetal aorta during normal gestation in bitches. Indian Journal of Animal Reproduction, 39(1), 41-43.

Veiga, G. A. L. (2012). Caracterização das alterações hemodinâmicas do útero em cadelas com hiperplasia endometrial cística-piometra. [Tese de doutorado, Universidade de São Paulo]. VETTESES.

Veiga, G. A. L., Miziara, R. H., Angrimani, D. S. R., Papa, P. C, Cogliati, B. \& Vannucchi, C. I. (2017). Cystic endometrial hyperplasia-pyometra syndrome in bitches: identification of hemodynamic, inflammatory, and cell proliferation changes. Biol Reprod, 96(1), 58-69. Doi:10.1095/biolreprod.116.140780.

Vermeulen, M. A. E. (2009). Ovarian Color-Doppler Ultrasonography to Predict Ovulation in the Bitch. [Master Thesis, Veterinary Medicine Louisiana State University]. Ultretch University Repository.

Zelli, R., Orlandi, R., Troisi, A., Cardinali, L. \& Polisca, A. Power and Pulsed Doppler Evaluation of Prostatic Artery Blood Flow in Normal and Benign Prostatic Hyperplasia-Affected Dogs. Reprod Dom Anim, 48, 768-773. Doi: 10.1111/rda.12159. 